Хлапук М. М., д.т.н., професор, Мошинський В. С., д.С.-г.н., професор, Безусяк О. В., к.т.н., доцент, Волк Л. Р., к.т.н., доцент (Національний університет водного господарства та природокористування, м. Рівне)

\title{
АНАЛІЗ РОЗВИТКУ ТЕОРІЇ РУХУ ПОТОКУ В ТРУБОПРОВОДАХ
}

В статті приведено аналіз літературних джерел щодо розвитку теорії руху потоку в трубопроводах. За узагальненими результатами аналізу та теоретичних досліджень розкрито зв'язок між ламінарним режимом руху та структурою потоку в трубопроводах. Ключові слова: теорія руху потоку, ламінарний режим, структура потоку, трубопроводи.

В сучасних умовах спостерігається тенденція розвитку в галузі гідроенергетики, теплоенергетики, гідротехнічного будівництва як у світі так і в Україні в цілому. Для успішного проектування великого ряду об'єктів необхідне проведення нових наукових досліджень та впроваджень у виробництво. Для підвищення ефективності і надійності гідротехнічних об'єктів постає питання щодо необхідності та удосконалення підходів до гідравлічного розрахунку напірних трубопроводів різного призначення, а саме розвиток теорії кінематичної структури потоку в них [1; 2].

Загальновідомо, що турбулентні течії $€$ найпоширенішою формою руху рідини і газів, які повсякденно зустрічаються в природі та в усіх областях техніки. При цьому вони відрізняються нескінченним різноманіттям. Найбільш прості з них - це рух в трубах, лотках, каналах тощо.

О. Рейнольдс вперше у 1895 році встановив існування двох режимів потоку - ламінарного та турбулентного.

На рис. 1, а та рис. 1, г наведено графіки залежності коефіцієнта гідравлічного опору $\lambda$ від числа Рейнольдса $R e$, на яких розкриті режими руху потоку в трубопроводах. Експериментальні точки, що приведені на графіках, отримані на основі унікальних експериментальних досліджень І. Нікурадзе та Ф.О. Шевельова [3-5].

Залежність коефіцієнта гідравлічного опору від числа Рейнольдса при ламінарному режимі руху рідини визначається за наступною формулою 


$$
\lambda_{\Omega}=\frac{64}{R e} .
$$

a)

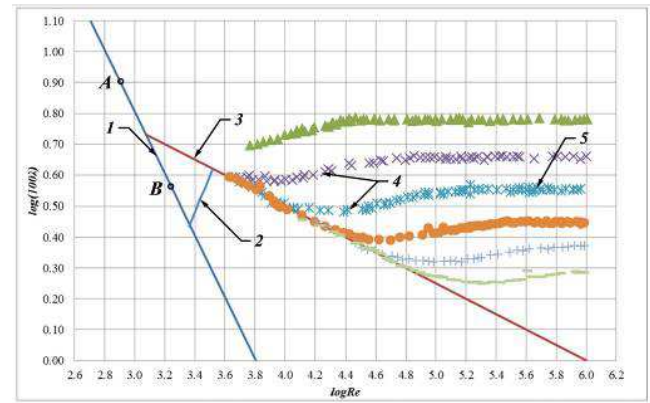

B)

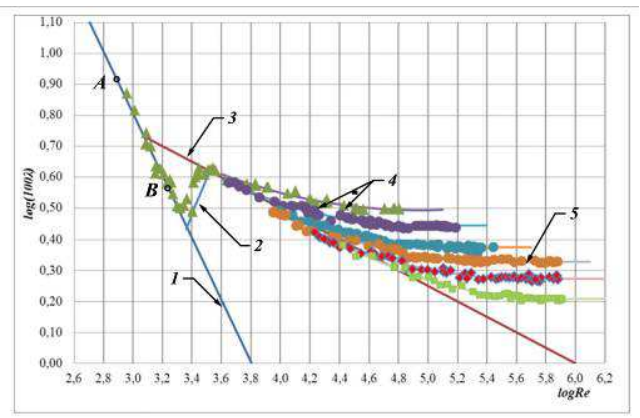

б)

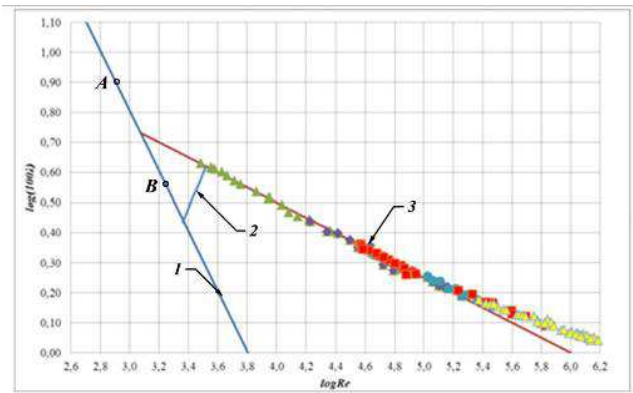

г)

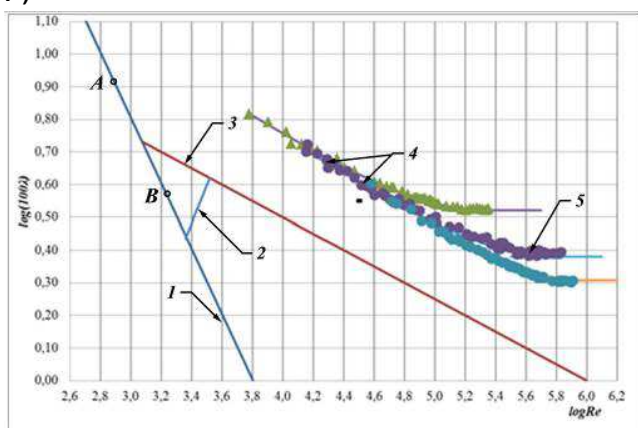

Рис. 1. Графіки залежності коефіцієнта гідравлічного опору від числа

Рейнольдса: $а$ - трубопроводи з однорідною шорсткістю (за даними І. Нікурадзе); б - трубопроводи з гідравлічно гладкою поверхнею (за даними І. Нікурадзе); в - нові сталеві трубопроводи (за даними Ф.О. Шевельова); $\Gamma$ - нові чавунні трубопроводи (за даними Ф.О. Шевельова); 1 - ламінарний

режим руху потоку; 2 - перехідна область; 3 - область гладкого руху

(Г. Блазіус); 4 - область доквадратичного опору;

5 - область квадратичного опору

При турбулентному режимі в області гладкого руху коефіцієнт гідравлічного опору від числа Рейнольдса визначають за формулою Г. Блазіуса

$$
\lambda_{\text {гл }}=\frac{0,3164}{R e^{0,25}} .
$$

При турбулентному режимі в областях доквадратичного та квадратичного руху потоку коефіцієнт гідравлічного опору залежить не тільки від числа Рейнольдса, а і від внутрішньої поверхні трубопроводу. Тому існує велика кількість залежностей, які $є$ в довідковій літературі $[1 ; 5]$. Всі вони рекомендовані тільки для конкретних умов 
(матеріал, вид шорсткості поверхні, висота виступів, відстань між ними, їх форма та розташування по поверхні). Адекватну залежність зміни коефіцієнта гідравлічного опору від всіх основних діючих факторів можна встановити тільки дослідним шляхом [5].

Необхідно відмітити, що графік залежності зміни коефіцієнта гідравлічного опору від числа Рейнольдса розкриває тільки режими руху, але не розкриває структури потоку, яку необхідно враховувати при гідравлічних розрахунках трубопроводів.

Одним з перших видатних вчених 19 століття, що займався розробкою теоретичних основ структури потоку $є$ С. Нав'є, який ввів у диференційне рівняння Л. Ейлера додаткові члени для врахування дотичних напружень, які виникають при наявності градієнта швидкості.

Розподіл дотичних напружень сил тертя відомий з основного рівняння рівномірного руху рідини (рис. 2) і виражається рівнянням

$$
\tau=\tau_{0} \frac{r}{r_{0}}=\rho \lambda \frac{\operatorname{Re}^{2} v^{2}}{8 d^{2}} \frac{r}{r_{0}},
$$

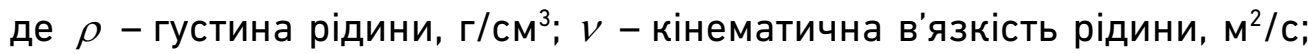
$d$ - діаметр трубопроводу, м; $r_{0}$ - внутрішній радіус трубопроводу, м; $r$ - відстань від осі труби до координати точки, м.

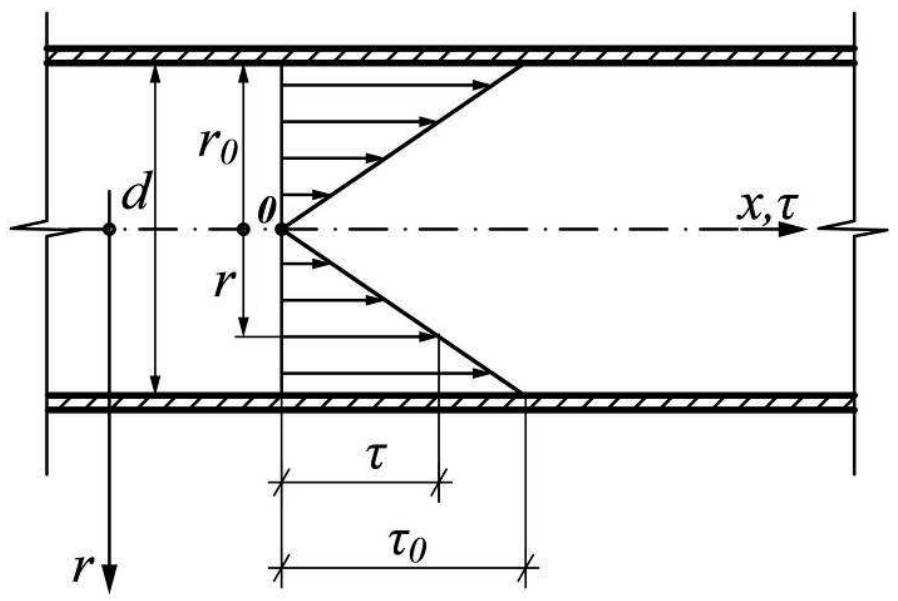

Рис. 2. Розподіл дотичних напружень сил тертя по живому перерізу в циліндричному трубопроводі

У 1845 році Дж. Стокс отримав рішення диференційного рівняння С. Нав'є. Його теоретичні результати повністю співпали з даними дослідів проведених у трубах малого діаметру при малих швидкостях (ламінарний режим руху) [1]. 
Рівняння Нав'є-Стокса в диференційній формі має вид

$$
\left.\begin{array}{l}
\frac{\partial u_{x}}{\partial t}+u_{x} \frac{\partial u_{x}}{\partial x}+u_{y} \frac{\partial u_{x}}{\partial y}+u_{z} \frac{\partial u_{x}}{\partial z}=F_{x}-\frac{1}{\rho} \frac{\partial p}{\partial x}-v\left(\frac{\partial^{2} u_{x}}{\partial x^{2}}+\frac{\partial^{2} u_{x}}{\partial y^{2}}+\frac{\partial^{2} u_{x}}{\partial z^{2}}\right) \\
\frac{\partial u_{y}}{\partial t}+u_{x} \frac{\partial u_{y}}{\partial x}+u_{y} \frac{\partial u_{y}}{\partial y}+u_{z} \frac{\partial u_{y}}{\partial z}=F_{y}-\frac{1}{\rho} \frac{\partial p}{\partial y}-v\left(\frac{\partial^{2} u_{y}}{\partial x^{2}}+\frac{\partial^{2} u_{y}}{\partial y^{2}}+\frac{\partial^{2} u_{y}}{\partial z^{2}}\right) \\
\frac{\partial u_{z}}{\partial t}+u_{x} \frac{\partial u_{z}}{\partial x}+u_{y} \frac{\partial u_{z}}{\partial y}+u_{z} \frac{\partial u_{z}}{\partial z}=F_{z}-\frac{1}{\rho} \frac{\partial p}{\partial z}-v\left(\frac{\partial^{2} u_{z}}{\partial x^{2}}+\frac{\partial^{2} u_{z}}{\partial y^{2}}+\frac{\partial^{2} u_{z}}{\partial z^{2}}\right)
\end{array}\right\},
$$

де $x, y, z$ - координати точки водного потоку; $u_{x}, u_{y}, u_{z}$ - проекції осередненої швидкості на координатні осі $0 x, 0 y, 0 z ; t$ - час; $F_{x}, F_{x}$, $F_{x}$ - проекції прискорення масових сил на координатні осі; $p$-тиск. Дж. Стокс для замкнення диференційного рівняння (4) врахував рівняння неперервності

$$
\frac{\partial u_{x}}{\partial x}+\frac{\partial u_{y}}{\partial y}+\frac{\partial u_{z}}{\partial z}=0,
$$

й прийняв наступні крайові умови:

- рух води усталений, тому часткові похідні

$$
\frac{\partial u_{x}}{\partial t}=0, \frac{\partial u_{y}}{\partial t}=0, \frac{\partial u_{z}}{\partial t}=0 ;
$$

- проекції прискорень масових сил на координатні осі

$$
F_{x}=0, F_{y}=0, F_{z}=-g ;
$$

- рух води відбувається у циліндричному трубопроводі радіусом $r_{0} \mathrm{i}$ довжиною $l$;

- рух води відбувається при наявності перепаду тиску $\Delta p$ в межах трубопроводу;

- при ламінарному режимі руху води вода має кінематичну в'язкість $v=f(T)$;

- лінії токів потоку розташовані симетрично й паралельно осі $0 x$, тому $u_{y}=0, u_{z}=0$;

- на внутрішній поверхні труби $\left(r=r_{0}\right)$, в наслідок прилипання до неї часток води, проекція осередненої швидкості їх становить $u_{x}=0$;

- на осі потоку $(r=0)$ похідна $\frac{d u_{x}}{d r}=0$.

Дж. Стокс встановив, що отримане рішення адекватно описує структуру потоку при ламінарному режимі для всіх точок, сукупність 
яких представлена на графіку Нікурадзе лінією 1 (рис. 1), для прикладу на графіках показані точки А і В.

1. Отримане рівняння розподілу осередненої швидкості руху рідини при ламінарному режимі (рис. 3).

$$
u_{x л}=\lambda \operatorname{Re}^{2} \frac{v}{8 d^{3}}\left(r_{0}^{2}-r^{2}\right) .
$$

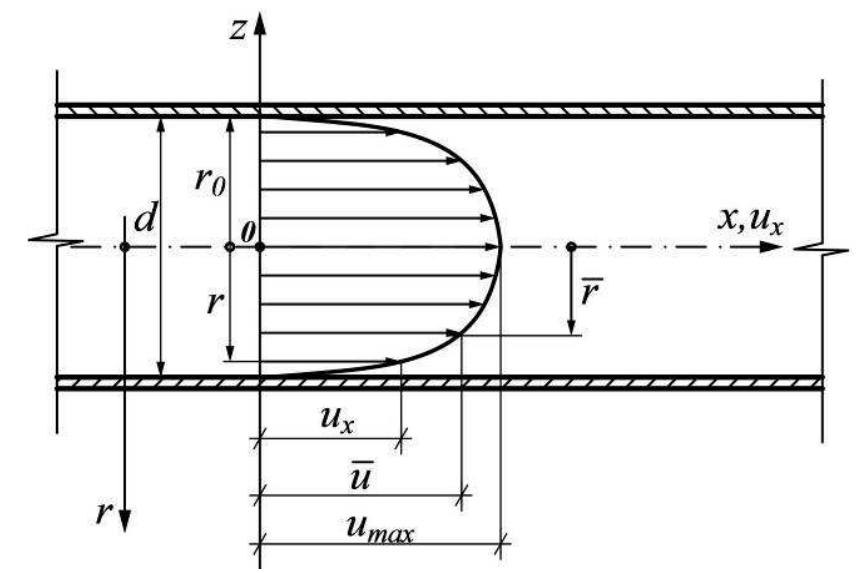

Рис. 3. Розподіл осередненої швидкості руху рідини

2. Визначена відстань від осі трубопроводу до точок, що мають середню швидкість

$$
\bar{r}=\frac{r_{0}}{\sqrt{2}} .
$$

3. Отримане значення максимальної швидкості потоку

$$
u_{x \max }=\lambda \operatorname{Re}^{2} \frac{v}{8 d^{3}} r_{0}^{2} .
$$

4. Визначене відношення максимальної швидкості до середньої в трубопроводі

$$
\frac{u_{x \max }}{\bar{u}_{x}}=2 .
$$

5. Отримане значення компонентів вихорів (рис. 4)

$$
\left.\begin{array}{c}
\omega_{x}=\frac{1}{2}\left(\frac{\partial u_{z}}{\partial y}-\frac{\partial u_{y}}{\partial z}\right)=0 \\
\omega_{y}=\frac{1}{2}\left(\frac{\partial u_{x}}{\partial z}-\frac{\partial u_{z}}{\partial x}\right)=-\lambda R e^{2} \frac{v}{8 d^{3}} z \\
\omega_{z}=\frac{1}{2}\left(\frac{\partial u_{y}}{\partial x}-\frac{\partial u_{x}}{\partial y}\right)=\lambda \operatorname{Re}^{2} \frac{v}{8 d^{3}} y
\end{array}\right\} .
$$


Доведено, що вихрові лінії є концентричними колами з радіусом $r$, центри яких розміщені на осі труби

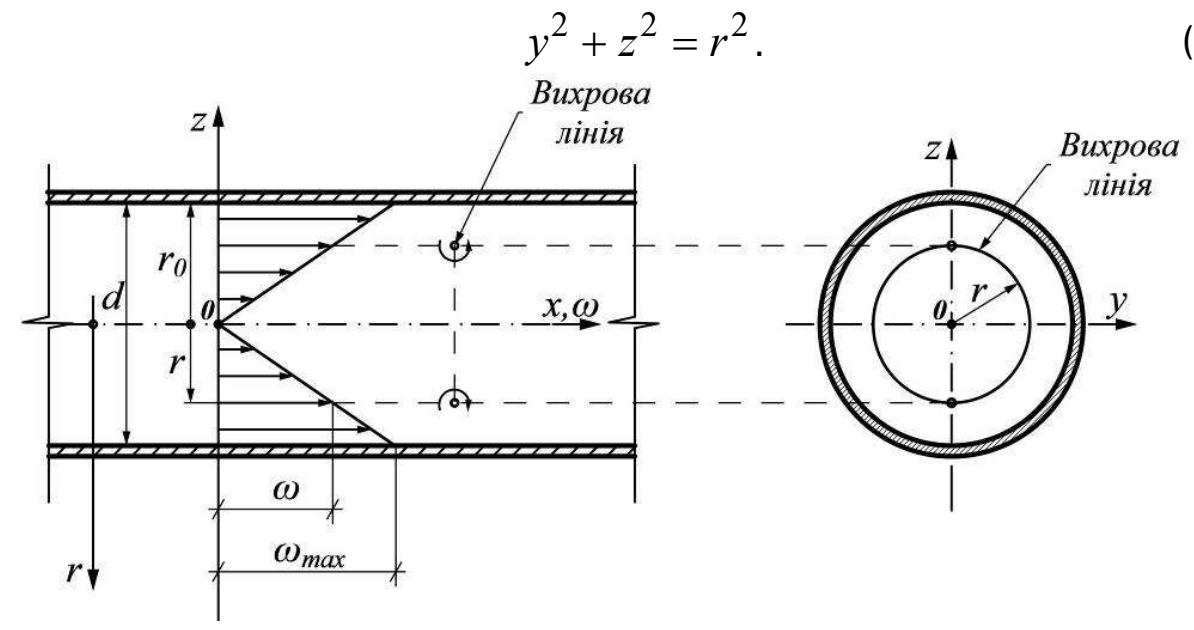

Рис. 4. Розподіл кутової швидкості обертання часток рідини по живому перерізу в циліндричному трубопроводі

Кутова швидкість обертання часток рідини потоку відносно вихрових ліній визначається за залежністю

$$
\omega=\sqrt{\omega_{x}{ }^{2}+\omega_{y}{ }^{2}+\omega_{z}{ }^{2}}=\lambda \operatorname{Re}^{2} \frac{v}{8 d^{3}} r .
$$

Величина кутової швидкості обертання часток на стінці трубопроводу $r=r_{0}$ набуває максимального свого значення

$$
\omega_{\max }=\operatorname{Re} \frac{v}{r_{0}^{2}} .
$$

6. Після інтегрування диференційного рівняння Нав'є-Стокса також отримано рівняння розподілу тиску в трубопроводі (рис. 5)

$$
p=p_{0}+\rho g\left(r_{0}+r\right),
$$

де $p_{0}$ - початковий тиск в трубопроводі, Па; $g$ - прискорення сили тяжіння, $g=9,81 \mathrm{~m} / \mathrm{c}^{2}$. 


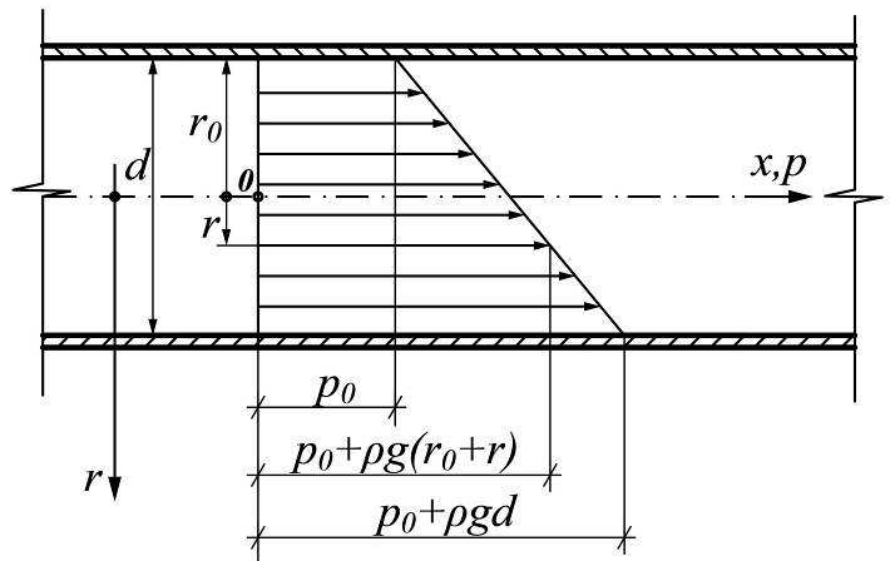

Рис. 5. Розподіл гідродинамічного тиску по живому перерізу в циліндричному трубопроводі

Висновок. В даній роботі всі залежності, які розкривають структуру потоку виражені через число Рейнольдса та коефіцієнт гідравлічного опору. Такий запис формул прийнято з метою, щоб показати зв'язок між режимом руху та структурою потоку.

Необхідно відмітити, що для турбулентного режиму аналогічного розкриття внутрішньої структури потоку досі не існує. Тому в наступних статтях будуть приведені спроби розкриття цієї проблеми.

1. Лойцянский Л. Г. Механика жидкости и газа. М.: Наука, 1978. 736 с. 2. Киселев П. Г. Справочник по гидравлическим расчетам. М. : Энергия, 1972. 316 c. 3. Nikuradse J. Gesetzmassigkeiten der turbulenten Strömung in glatten Rohren. Forsch. Arb. Ing. Wes., 1932. N. 356. 4. Nikuradse J. Strömungsgesetze in rauchen Rohren. Forsch. Ver. Dtsch. Ing. 1933. N. 361. 5. Шевелев Ф. А. Исследование основных гидравлических закономерностей турбулентного движения в трубах. М. : Госстройиздат,. 1953. 208 с. 6. Logarithmic scaling of turbulence in smooth- and rough-wall pipe flow / M. Hultmark, M. Vallikivi, S. C. C. Bailey, A. J. Smits. J. Fluid Mech. Cambridge University Press, 2013. Vol. 728. Pp. 376-395.

\section{REFERENCES:}

1. Loitsianskii L. H. Mekhanika zhidkosti i haza. M. : Nauka, 1978. 736 s. 2. Kiselev P. H. Spravochnik po hidravlicheskim raschetam. M. : Enerhiia, 1972. 316 s. 3. Nikuradse J. Gesetzmassigkeiten der turbulenten Strömung in glatten Rohren. Forsch. Arb. Ing. Wes., 1932. N. 356. 4. Nikuradse J. Strömungsgesetze in rauchen Rohren. Forsch. Ver. Dtsch. Ing. 1933. N. 361. 5. Shevelev F. A. Issledovanie osnovnykh hidravlicheskikh zakonomernostei turbulentnoho dvizheniia $\mathrm{v}$ trubakh. M. : Hosstroiizdat,. 1953. $208 \mathrm{~s}$. 
6. Logarithmic scaling of turbulence in smooth- and rough-wall pipe flow / M. Hultmark, M. Vallikivi, S. C. C. Bailey, A. J. Smits. J. Fluid Mech. Cambridge University Press, 2013. Vol. 728. Pp. 376-395.

Khlapuk M. M., Doctor of Engineering, Professor, Moshynskyi V. S., Doctor of Agricultural Sciences, Professor, Bezusiak 0. V., Candidate of Engineering (Ph.D.), Associate Professor, Volk L. R., Candidate of Engineering (Ph.D.), Associate Professor (National University of Water and Environmental Engineering, Rivne)

\section{FLOW THEORY DEVELOPMENT ANALYSIS IN THE PIPES}

In order to improve the reliability of the hydraulic structures, it is necessary to improve the approach of the hydraulic calculation of pressure pipes. That is, we need to develop this theory of kinematic flow structure. The article describes the literature analysis about the development of flow theory in the pipes.

It is noted that the graph of the dependence of the friction factor on the Reynolds number reveals only the flow regimes, but does not reveal the flow structure, which is necessary when considering the hydraulic calculations of the pipes. J. Stokes obtained the solution of the differential equation of $\mathbf{S}$. Navier. His theoretical results completely coincide with the data of experiments conducted in small diameter pipes at low velocity (laminar flow regime). To close the differential equation, he considered the continuity equation and accepted the boundary conditions. J. Stokes found that the result obtained adequately describes the structure of the laminar flow for all points on the Nikuradze graph.

The results of the analysis and the theoretical studies summarized. The relationship between the flow laminar regime and the flow structure in the pipes has described. Equations for calculating flow parameters determined: the equation of distribution of the averaged flow velocity in laminar flow regime, the distance from the pipe axis to the points with average velocities, the value of the maximum flow velocity, the ratio of the maximum velocity to the average flow velocity in the pipe, the value of the vortex components. It is proved that vortex lines are concentric circles whose centres located on the pipe axis. The equation of the particles rotation components of the flow and the maximum value of the angular velocity of rotation of the particles on the inner surface of the pipe were obtained. After integrating the 
Navier-Stokes differential equation, the pressure distribution equation in the pipe obtained.

All equations that determine the flow structure expressed by Reynolds number and pipe friction factor. Such formulas have adopted to show the relationship between the flow regime and the flow structure. The flow structure for turbulent regime is still unknown. Therefore, we will describe the solution of this problem in the future articles.

Keywords: flow theory, laminar flow, laminar flow regime, flow structure, pipes.

Хлапук Н. Н., А.т.н., профессор, Мошинский В. С., д.С.-Х.н., профессор, Безусяк А. В., к.т.н., доцент, Волк Л. Р., к.т.н., доцент (Национальный университет водного хозяйства и природопользования, г. Ровно)

\section{АНАЛИЗ РАЗВИТИЯ ТЕОРИЙ ДВИЖЕНИЯ ПОТОКА В ТРУБОПРОВОДАХ}

В статье приведены анализ литературных источников по развитию теории движения потока в трубопроводах. По обобщенным результатам анализа и теоретических исследований раскрыта связь между ламинарным режимом движения и структурой потока в трубопроводах.

Ключевые слова: теория движения потока, ламинарный режим, структура потока, трубопроводы. 